\title{
INVOLUSI POLITIK PEMEKARAN, ETNISITAS, DAN AGAMA: TANTANGAN REFORMASI BIROKRASI KASUS MALUKU UTARA
}

\section{INVOLUTION POLITICS PROLIFERATION, ETHNICITY, AND RELIGION: CASE CHALLENGES REFORMS NORTH MALUKU}

\author{
Zuly Qodir \\ Jurusan Ilmu Pemerintahan Fisipol, Universitas Muhammadiyah Yogyakarta \\ Jalan Lingkar Selatan Tamantirto, Bantul - Yogyakarta \\ E-mail: zuly_qodir@yahoo.com \\ Diterima: 13 Oktober 2012; direvisi: 20 Oktober 2012; disetujui: 10 Desember 2012
}

\begin{abstract}
Abstrak
Penelitian ini bertujuan memberikan penjelasan pertarungan politik lokal berbasiskan perspektif politik etnis dan agama sebagaimana dikemukakan Clifford Geertz. Dengan demikian pembahasan pada tulisan ini berkisar pada terjadinya pertarungan, perebutan, klaim dan reproduksi identitas etnis dan agama dalam dinamika politik lokal sebagai bagian dari apa yang saya sebut sebagai involusi pemekaran. Kajian ini hendak menjawab pertanyaan dan menjelaskan masalah-masalah yang berkaitan dengan permasalahan pemekaran yang terjadi di Ternate, Maluku Utara, sebagai sebuah daerah pemekaran. Pertanyaan yang hendak dijawab adalah bagaimana pengaruh etnisitas dalam konflik pemekaran, bagaimana peran elit-elit agama dan elit politik dalam konflik pemekaran yang telah terjadi selama sebelas tahun, sejak tahun 20012012. Untuk menjawab pertanyaan diatas, kajian ini mendasarkan pada wawancara mendalam kepada tokoh masyarakat, tokoh agama, aktivis perempuan, politisi, akademisi, dan birokrat di Daerah Maluku Utara. Data yang diperoleh dianalisis menggunakan analisis kualititif eksplanatif, sehingga tergambar kaitan antar faktor dalam konflik pemekaran.

Kata kunci: involusi politik, pemekaran, etnisitas, dan agama.
\end{abstract}

\begin{abstract}
This study aims to provide an explanation based on local political battles ethnic and religious politics perspective as expressed Clifford Geertz. Thus, the discussion in this paper revolves around the fight, the struggle, claims and reproduction of ethnic identity and religion in the dynamics of local politics as part of what I refer to as involution division. This study is going to answer questions and clarify issues relating to the problems of expansion that occurred in Ternate, North Maluku, as an area of expansion. The question being answered is how the expansion of ethnicity in conflict, the role of religious elites and political elites in conflict expansion that has occurred over the last eleven years, since 2001-2012. To answer these questions, the study was based on in-depth interviews community leaders, religious leaders, women activists, politicians, academics, and bureaucrats in the regions of North Maluku. The data obtained were analyzed using analysis kualititif explanative thus illustrated the link between the expansion factor in the conflict.
\end{abstract}

Keywords: political involution, expansion, ethnicity, and religion.

\section{PENDAHULUAN}

Maluku Utara 1999 adalah kota yang baru saja Mekar dari Pulau Ambon sebagai Provinsi Induk. Gubernur M. Thaib Armayn ditetapkan oleh Departemen Dalam Negeri mengalahkan Abdul Gafur, yang menang dalam pemilihan Gubernur Maluku Utara tetapi gagal menjadi gubenur karena kalah dalam sidang Mahkamah Konstitusi dengan dugaan adanya kecurangan dalam Pemilihan Gubernur Maluku Utara.

Tahun 1999, Desember di Ambon terjadi tragedi berdarah di Masjid Al Fatah yang berbuah kerusuhan antaretnis dan agama sangat besar dan terdengar diseluruh Indonesia bahkan internasional. Korban demikian banyak bergelimpangan dari pihak yang berkonflik (Islam versus Kristen). Masingmasing pihak membentuk laskar (milisi) perang. Kristen membentuk Laskar Kristus. Islam membentuk Laskar Mujahid. Korban tak kurang dari 5.000 orang dari dua belah pihak. Rumah dibakar dan dirusak hampir separuh kota Ambon. Bahkan pembakaran dan pembunuhan menyisir ke daerah-daerah seperti Jazirah Hitu, Leihitu, Soya dan sekitarnya. Puluhan rumah ibadah dirusak dimana oleh agama dilarang terjadi perusakan dan pertumpahan darah di rumah Tuhan.

Ambon sesungguhnya sebuah provinsi eksotik. Pulau yang dikelilingi pantai nan indah elok akhirnya bersimbah darah karena konflik yang semula sepele. Disebabkan karena antara tukang angkot dengan penduduk setempat yang hendak memaksa sopir 
angkot. Antara sopir dan preman yang berbeda etnis dan agama, kemudian saling mengancam dan bahkan saling membunuh. Dua belah pihak hancur lebur dan babak belur saling membunuh. Pela gandong hancur, hubungan sosial rusak. Pela dan gandong, seakan tak berakar di masyarakat sama sekali. Konflik antaretnis dan agama membuat Ambon menjadi provinsi yang menakutkan dan mengkhawatirkan. Ketakutan menjadi bagian para penduduk setempat. Pendatang pun dipaksa tidak bersedia datang ke Pulau RempahRempah yang kaya cengkeh, pala dan lada. Darah segar pernah mengalir deras di pulau beribu ribu rempah ini.

Ambon tentu saja bukan daerah satu-satunya yang dilanda konflik kekerasan berdarah. Sambas Kalimantan Barat adalah contoh lain. Kota Waringin Barat dan Kota Waringin Timur di Kalimantan Tengah contoh lain lagi. Bahkan Palangkaraya adalah contoh terjadinya kekerasan etnis yang juga mengerikan. Sampit adalah tempat yang mengerikan untuk pendatang Bugis, Buton, Makasar dan juga Madura. Darah segar dan harta benda merupakan dua hal yang tidak pernah luput dari dampak konflik kekerasan yang terjadi di sebuah daerah.

Di atas semua itu yang dapat dikatakan adalah daerah baru untuk kelompok masyarakat tertentu yang dikenal dengan istilah masyarakat pendatang. Pendatang karena faktor transmigrasi lokal, transmigrasi massal (bedol desa) atau bahkan sekedar berpindah tempat untuk mencari nafkah dalam kehidupan sehari-hari. Ambon, Ternate, Kalimantan Timur, Kalimantan Barat dan Kalimantan Tengah adalah lokasi yang menjadi tujuan perpindahan penduduk dari daerah asalnya.

Sebenarnya perpindahan penduduk tidak identik dengan kekerasan massal (komunal) yang terjadi sejak tahun 1998 di Indonesia, sebab perpindahan penduduk di Indonesia telah terjadi jauh sebelum tahun 1980, ke berbagai wilayah di Indonesia, seperti Lampung, Sumatera Selatan bahkan Papua. Namun belakangan sejak tahun 1999 tampaknya perpindahan penduduk menjadi masalah serius soal kependudukan Indonesia. Istilah pendatang dan asli menjadi kosa kata baru untuk masalah kependudukan dan konflik yang bersifat kedaerahan. Konflik di beberapa daerah di Indonesia, sebagaimana dikatakan Gerry van Klinken dan Nordoth sebenarnya sering berhubungan dengan persoalan sumber-sumber ekonomi dan politik dalam sebuah wilayah. Daerah yang semula seakan-akan menjadi wilayah kekuasaan etnis dan agama tertentu kemudian berkembang menjadi kekuasaan etnis dengan agama tertentu sehingga etnis yang sebelumnya berkuasa menjadi tersaingi dalam perebutan wilayah kekuasaan; baik politik maupun ekonomi. (Klinken, 2008)

Selain persoalan perpindahan penduduk di dalam suatu wilayah (provinsi) masalah pemekaran wilayah merupakan persoalan lain yang belakangan menjadi masalah serius di nusantara. Di nusantara sendiri sampai dengan tahun 2009 telah terjadi pemekaran yang demikian banyak untuk tingkat kabupaten/kota di Indonesia. Sampai tahun 2009 yang lalu tidak kurang dari 400 kabupaten/Kota baru terbentuk di Indonesia. (Depdagri, 2009).

Daerah pemekaran merupakan salah satu daerah yang potensial terjadinya kekerasan massal. Beberapa daerah konflik kekerasan memang daerah lama. Tetapi pertambahan penduduk merupakan salah satu penyebabnya. Sambas di Kalimantan Barat adalah contoh paling nyata dengan pertambahan penduduk asal Madura yang dibeberapa daerah berposisi ekonomi menjadi lebih mapan sehingga mempengaruhi siklus ekonomi dan politik serta komposisi keagamaan masyarakat setempat.

Ambon sangat jelas memberikan penjelasan tentang pertambahan penduduk dan kondisi sosial ekonomi dan agama yang kemudian berubah. Dari dominan Kristen menjadi berimbang. Penduduk Muslim 45\%, Kristen 55\%. Kondisi seperti itu berpengaruh pada perilaku politik dan perilaku sosial masyarakat Ambon yang selama bertahun-tahun berada dalam posisi tanpa persaingan karena memang tidak ada kompetitor. Ambon adalah penguasa sekaligus pemilik bahkan pewaris tunggal Pulau Rempah-rempah. Namun semuanya berubah sejak program transmigrasi bedol desa dan migrasi penduduk dari provinsi lain seperti Sulawesi, Jawa dan Kalimantan. Kompetisi pun akhirnya terjadi di sana. Kompetisi tidak selalu berakhir dengan hasil yang baik. Seringkali kekalahan membawa luka dan dendam kesumat. Disebabkan luka serta dendam kesumat itulah yang membuat kerusuhan seringkali menjadi hasil akhir dari persoalan persaingan antar etnis dan sekaligus agama.

Etnis dan agama oleh antropolog Malinowsky (1982) dikatakan sebagai dua entitas yang sampai saat ini, saat dunia menginjak era modern bahkan post modernisme akan menjadi salah satu perekat sekaligus ketegangan, kerengganan antar elemen dalam masyarakat yang paling mujarab. Etnisitas dan agama merupakan dua entitas yang bersifat bagai pedang bermata dua. Membuat integrasi sekaligus membuat disintegrasi antar anggota masyarakat. Terlebih jika etnisitas dan agama dipahami secara sempit (narrow religion and ethnicity) akan dengan mudah mendorong adanya semangat gerakan perlawanan berdasarkan sentimen etnisitas dan agama tertentu. Inilah mengapa di beberapa daerah persoalan etnisitas dan agama masih dikatakan rentan dan menguntungkan. Rentan terkait akan kemungkinan konflik antar etnis. Menguntungkan karena akan membawa dampak pada asosiasi-asosiasi dan akomodasi kebudayaan.

Daerah pemekaran, ceritanya akan jauh lebih panjang dan memberikan fakta lain. Ada pejabat, tetapi seringkali tidak ada ketentraman dan pelayanan. Dalam bahasa lain miskin pelayanan dan keamanan. Hal ini karena masing-masing pejabat sibuk dengan urusannya sendiri. Urusan memperkuat posisi dan memperlebar kekuasaan. Inilah sebuah resiko dari 
pemekaran yang menjadi basis dari pemikirannya adalah kekuasaan bukan pelayanan publik. Kekuasaan dapat diperoleh dengan pelbagai mekanisme seperti membangun sentimen etnis dan agama. Pola semacam ini pernah dikatakan oleh Clifford Geertz sebagai politik berbasis aliran, agama dan etnisitas, sekalipun telah banyak dikritik karena dalam hal penempatan kategori priyayi dianggap gagal menjelaskan kategorisasi etnisitas dan keagamaan. Tetapi untuk kasus etnis dan agama sebagai aliran tampaknya penjelasan Clifford Geertz masih bisa dipertimbangkan untuk menjawab pertanyaan: apakah pola politik kekuasaan berbasis etnisitas dan agama masih berlangsung di Indonesia? Secara spesifik lagi apakah etnisitas dan agama masih berlangsung dalam politik pemekaran?

Teori yang dipergunakan dalam memahami kasus Maluku Utara adalah politik identitas yang dialamatkan pada etnisitas dan agama masyarakat yang tinggal dalam sebuah wilayah. Etnisitas dan agama menjadi perekat identitas yang masih dipercaya dalam berbagai pergulatan politik lokal sehingga banyak pihak mempergunakan dua entitas ini untuk kepentingan politiknya. Etnisitas dan agama bermain dalam perebutan posisi-posisi politik tertentu yang berkaitan erat dengan tokoh politik yang ada di wilayah. Etnisitas dan agama kemudian direproduksi dalam pergulatan politik pemekaran yang menjadi bagian dari kehidupan desentralisasi di Indonesia. Dua entitas yang berbeda tersebut sampai sekarang di lapangan politik masih menjadi bagian penting dalam konstruksi politik identitas yang berkembang sejak sebelum tahun 1950-an sebagaimana Cliffordz geertz menemukan dalam kasus keagamaan di Jawa waktu itu dan di kawasan Afrika (Maroko dan Sudan) ketika itu yang disimpulkan dalam Islam Observed (1960) maupun dalam After the Fact (1957).

Ikatan-ikatan solidaritas agama dan afiliasi politik pun terjadi dalam kurun waktu yang cukup panjang. Religion of Java (1957) yang ditulis berdasarkan peneltian Clifford Geertz di Desa Pare (Jawa Timur) menggambarkan masalah afiliasi keagamaan dan politik, selain afiliasi kultural dan sosial yang terjadi. Tiga bagian dari masyarakat yang digambarkan Geertz tentang santri, abangan dan priyayi, ketika itu memberikan penjelasan bahwa dalam masyarakat terdapat segmentasi tentang kelompok sosial dan politik yang kemudian diperjalas oleh Herbet Fith dan Lance Castles, tentang partai berbasiskan aliran keagamaan dan etnisitas. Terdapat partai berafiliasi muslim seperti Masyumi, NU, yang cenderung dianut oleh penduduk Jawa, kaum Jawa nasionalis yang berafiliasi pada Partai Nasionalis Indonesia (PNI) yang dianut oleh penduduk Jawa, dan sebagian para petani yang cukup kaya, partai sosialis (PSI) yang dianut oleh sebagian besar kaum terdidik Indonesia dan etnis luar Jawa (Sumatra), partai Parkindo yang berafiliasi pada umat Kristen dan Indonesia Timur khususnya.
Dari penjelasan ringkas secara teoritik tersebut sebenarnya dapat dipahami sekalipun dalam perjalanan sejarahnya telah banyak perubahan yang signifikan dalam hal pengelompokan sosial keagamaan, sebagaimana dikatakan Kuntowijoyo, dan Robert Hefner bahwa di Indonesia telah terjadi pembelahan afiliasi sosial politik dan keagamaan yang relatif baru sehingga muncul apa yang dinamakan kelas menengah baru dalam hal afiliasi keagamaan dan politik. Dalam keagamaan muncul kelas menengah muslim yang Kuntowijoyo, dalam Muslim Tanpa Masjid, (2001) menyebutnya dengan istilah "Muslim Tanpa Masjid". Sementara Robert Hefner dalam Civil Islam, 200, menyebutnya dengan istilah "Muslim Akomodatif" bahkan muslim rezimis untuk menyebut kelas menengah muslim yang masuk dalam lingkaran kekuasaan zaman akhir Orde Baru sampai tumbangnya Orde Baru. Kategorisasi santri baru dan religio nationality serta ethnic nationalism merupakan pengaktegorian yang muncul sejak tahun 1990-an di Indonesia untuk menggambarkan perjalanan politik etnis dan agama sebagai bentuk nyata politik identitas di Indonesia.

Persoalan identitas agama dan etnis, dengan begitu menjadi persoalan yang telah terjadi sejak tahun 1950-an, 1960-an, 1970-an, 1980-an, 1990-an sampai tahun 2000-an dalam berbagai manifestasinya. Tahun 2000-an menjadi manifestasi dalam berbagai persoalan pemekaran daerah yang muncul sejak era reformasi Indonesia tahun 1998. Pemekaran menjadi semangat baru dalam politik identitas yang tidak jarang membawa korban jiwa dan tentu saja harta benda warga masyarakat yang sama-sama berada dalam sebuah wilayah tertentu. Terdapat banyak kasus mengenai masalah kekerasan karena etnistas dan identitas dalam pemekaran. Masyarakat Tapanuli Selatan yang harus mengakhiri riwayat hidup Mohammad Abdullah Angkat sebagai Ketua DPRD Sumatera Utara (Medan) karena terbunuh dalam persoalan pemekaran Tapanuli Selatan adalah contoh paling jelas. Pembakaran kantor Walikota dan Gubernur Ambon adalah bentuk lain lagi. Demikian pula pembakaran Kantor Kecamatan di Kao Malifut adalah bentuk kemarahan karena pemekaran di Maluku Utara. Pembakaran kantor DPRD NTB adalah bentuk kemarahan masyarakat terkait soal politik pemekaran yang terjadi di Indonesia.

Dua entitas, agama dan etnisitas tampak menjadi bagian dalam kehidupan politik Indonesia sejak tahun 1950-an sebagaimana Clifford Geertz kemukakan sampai dengan era 2000-an dimana zaman telah banyak mengalami perubahan, utamanya dalam hal kultur dan teknologi. Tetapi dua entitas ini masih menjadi idola dalam politik Indonesia. Hal seperti itu tentu menimbulkan banyak pertanyaan yang membutuhkan uraian untuk memberikan argumen sampai-sampai dimanakah sebenarnya ikatan etnisitas dan religius menjadi bagian dalam politik, khususnya dalam era politik pemekaran atau desentralisasi 
sebagai bagian dari demokrasi yang terjadi di provinsi Maluku Utara.

\section{METODE PENELITIAN}

Penelitian ini merupakan penelitian yang bersifat induktif kualitatif dengan mengambil fokus lokasi di Provinsi Maluku Utara, yang merupakan wilayah dengan ketegangan atau suhu politik sangat tinggi disamping suhu kekerasan antar warga masyarakat juga demikian tinggi sehingga konflik berdarah merupakan bagian dari kehidupan mereka dengan pemicu masalah-masalah yang sepele, seperti soal nonton main bola atau soal nonton pertunjukkan konser musik.

Penelitian ini fokus pada masalah politik yang muncul di daerah pemekaran seperti Maluku Utara yang merupakan wilayah pemekaran sejak tahun 1999 yang lalu dan sampai sekarang terdapat wilayah yang tidak kunjung selesai karena pemekaran tersebut. Persoalan pemekaran wilayah kemudian terus ramai menjadi konsumsi politik ketika menghadapi Pemilukada (Pemilu Bupati maupun Kota) juga Pemilu Legislatif demikian ramai diperebutkan oleh masing-masing kandidat dengan latar belakang etnis dan agama yang terdapat di Maluku Utara.

Riset ini mendasarkan pada data lapangan (dengan observasi lapangan yang dilakukan selama enam bulan), melakukan wawancara mendalam dengan berbagai narasumber yang kompeten dalam bidang politik pemekaran dan kaitannya dengan agama maupun etnisitas, melakukan kajian kepustakaan atas literatur ataupun hasil-hasil penelitian yang telah dilakukan sebelumnya. Hasil temuan lapangan dan kajian pustaka dianalisis dengan pendekatan sosiologis; khususnya sosiologi etnis dan agama yang difokuskan pada perspektif induktif analitik (thick description) sebagaimana dikemukakan oleh para antroplog semacam Clifford Geertz) dan Borislav Malinowsky.

\section{HASIL DAN PEMBAHASAN}

\section{Reproduksi Politik Pemekaran Berbasiskan Etnisitas dan Agama}

Ada pertarungan yang keras dalam etnis dan agama sebagai basisnya di wilayah pemekaran. Riset ini menunjukkan bahwa di Maluku Utara, Kabupaten Halmahera Utara dan Halmahera Barat, perilaku elit lokal (bupati), politisi partai bahkan sebagian elit masyarakat membuat dramaturgi yang sangat menghipnotis tentang basis etnisitas dan agama untuk tetap bertahan atau pindah dalam sebuah wilayah baru. Reproduksi etnisitas dan tradisi yang bertahun-tahun lamanya dianut direproduksi dalam konflik dua wilayah yang tak kunjung usai sampai sekarang sekalipun sudah sepuluh tahun bahkan menginjak 12 tahun (sejak 1999 hingga 2011). Tidak terlalu banyak riset yang menitikberatkan pada analisis etnis dan agama dalam proses pemekaran sebagai bagian penting dalam konflik. Ada beberapa yang mengkaji soal konflik etnis dan agama dalam pemekaran seperti (Rizal Panggabean, 2002), ketika mengkaji pola kekerasan kolektif di Indonesia sejak tahun 19902003, tetapi tidak khusus masalah pemekaran.

Drama tentang sentimen etnis dan agama menjadi buah bibir di masyarakat pendukung atau penentang atas wilayah baru. Halmahera Barat direproduksi sebagai daerah yang berlatar belakang etnis Jailolo, Bacan, Tobelo dan Tobaru agak sering bahkan seringkali dikonstruksikan akan sulit bila harus bergabung dengan wilayah yang etnisitasnya berbeda dan dengan tradisi berbeda pula. Reproduksi sejarah etnitas dan agama menjadi bagian dari persoalan yang melanda menjadi bagian dalam pemekaran Maluku Utara sampai saat ini. Konstruksi tentang etnisitas dan agama pun berkembang dalam dialog-dialog keseharian di masyarakat.

Di pasar, angkutan darat, angkutan laut dan tempat keramaian seperti lapangan sepak bola (karena masyarakat suka main dan menonton bola) maka reproduksi etnisitas dan agama berlangsung dengan nyaris sempurna. Bagaimana reproduksi bahwa Jailolo adalah "asal mula" etnis di Halmahera Barat yang menyebar ke enam desa di kawasan Halmahera Utara yang beribu kota di Tobelo. Jailolo menjadi penting dikemukakan karena merupakan kecamatan pertama sebelum terjadi pemekaran di Halmahera Barat. Selain itu di Jailolo terletak kerajaan (Kesultanan Bacan) yang dianggap sebagai asal usul masyarakat Halmahera. Oleh sebab itu tetap harus menjadi satu dengan Halmahera Barat siapapun masyarakatnya. Berkaitan dengan reproduksi yang dikembangkan adalah hal yang tidak mungkin etnis Jailolo dan Bacan perpindah ke wilayah yang bukan tanah kelahirannya. Tanah kelahirannya adalah Halmahera Barat bukan Halmahera Utara. Reproduksi akan etnisitas dan agama di lapangan bola bukan hal yang aneh kemudian membuahkan kekerasan fisik ketika terjadi pertandingan antar desa atau antar kecamatan. Bermula dari ejekan biasa kemudian berubah menjadi ejekan antaretnis dan agama yang berbuah kekerasan fisik pada salah satu pihak yang bertanding.

Dalam sebuah pertemuan di Akelamo bulan 19 Agustus, 2010, dapat menggambarkan bahwa persoalan etnisitas menjadi hal yang sangat serius dalam elit lokal Maluku Utara, misalnya, mereka mengatakan demikian: FP dan AF mengatakan: "Kami yang hadir disini, akan mempertahankan sampai titik darah penghabisan tetap menjadi penduduk Halmahera Barat, ketimbang harus menjadi penduduk Halmahera Utara. Sekalipun kami akan diberi segepok uang dana comdev dari PT NHM. Tidak akan kami berubah pendirian menjadi penduduk Halmahera Barat. Secara historis kami adalah orang Jailolo dan Bacan. Nenek moyang kami adalah orang Jailolo dan Bacan bukan Tobelo. Semua ini hanyalah akal-akalan para elit politik seperti Gubernur dan Bupati Halmahera Barat dan Timur yang memperalat penduduk Jailolo untuk saling konflik karena mereka 
mendapatkan untung dengan masyarakat terus berkonflik. Darah segar kami tumpah pun tidak masalah asalkan tetap menjadi bagian dari Halmahera Barat. Siapapun yang mengajak kami bergabung ke Halmahera Utara akan kami lawan ".

Jika kita mengkaji lebih dalam soal proses pemekaran dan transformasi kekuasaan daerah dan pusat akan didapatkan bahwa tidak ada hal yang bersifat gratis dan sekalipun harus mengorbankan hal yang sangat penting seperti nyawa manusia dan harta benda yang telah dikumpulkan. Bahkan lahan kehidupan lainnya seperti pertanian dan perikanan. Dalam banyak kasus seperti di Halmahera Barat dan Halmahera Utara karena masyarakat selalu diperlakukan dalam politik etnis dan agama maka kehidupan mereka menjadi tidak sejahtera dan dilanda kemiskinan, namun masyarakat tak kuasa menghadang bentuk-bentuk politisisasi etnis dan agama oleh kelompok elit lokal. Kekuasaan reproduski etnis dan agama dalam politik pemekaran adalah elit lokal, baik kepala desa, pejabat kecamatan, pemerintah daerah (kabupaten maupun pemerintah provinsi). Masyarakat adalah pendorong gerbong kaum elit yang seringkali lebih beruntung dalam konflik daerah pemekaran.

Hal yang juga, jika kita hendak mengkaji soal apa yang dilakukan oleh pejabat daerah (bupati) sebenarnya kita seringkali mendapatkan apa yang dalam bahasa popular sekarang adalah adanya transaksi politik pemekaran dengan sesama elit lokal dan elit pusat. Salah satu sarana transaksi politik pemekaran adalah etnisitas dan agama. Masyhur dan cukup mujarab sebab sentimen etnis dan agama seringkali menjadi bagian sejak kelahirannya. Reproduksi tentang kelahiran etnis dan agama menjadi jelas untuk mainan politik kepentingan elit lokal maupun pusat untuk mendapatkan untung. Dalam ungkapan penduduk lokal sering kita dengar bahwa para pejabat dearah konflik di Maluku Utara bermain mata. Mereka bermain golf bersama dan sering bertemu tetapi masalah konflik enam desa tak pula kunjung selesai. Ada segepok uang yang digadanggadang disana. Masyarakat benar-benar menjadi korban politik elit daerah.

Jika reproduksi etnisitas berlangsung pada ruang-ruang seperti lapangan bola maupun angkutan, pasar dan pusat-pusat keramaian, reproduksi agama berlangsung dalam ruang yang tak kalah menariknya. Masjid, mushola, gereja dan pengajian-pengajian adalah ruang yang paling popular untuk membuat konstruksi agama sebagai bagian dari sentimen masyarakat yang terkena dampak pemekaran. Masjid, mushola, gereja dan pengajian-pengajian adalah lahan yang selama ini menjadi pusat membangun reproduksi sentimen etnisitas dan keagamaan. Kebetulan di Halmahera Barat dan Halmahera Utara agamanya adalah Islam dan Kristen, maka gereja dan Masjid adalah pusat yang paling popular menjadi ruang mengkonstruksikan tentang siapa sebenarnya mereka. Siapa mereka dan kelompok mana yang dianggap menjadi bagiannya serta lawan politiknya tidak jarang dikonstruksikan dan direproduksi dalam tempattempat ibadah. Tempat ibadah bukan hanya untuk membaca dan membawa umat pada kesalehan individual pada Tuhan, tetapi sekaligus membawa umat pada sentimen politik tertentu berdasarkan kepentingan konstruksi elit agama dan elit politik.

Dalam sebuah Khutbah Jumat yang diselenggarakan di Halmahera Barat, 17 Agustus, khatib mengkonstruksi bagaimana Sultan Ternate adalah benar-benar syayidin panata agama yang harus ditaati oleh warga Maluku Utara. Sultan Ternate adalah tokoh pemersatu dan penjaga keamanan masyarakat, sekaligus pemberi kesejahteraan masyarakat. Oleh sebab itu, sebelum Sultan memutuskan apakah enam desa menjadi wilayah Kabupaten Halmahera Utara atau Halmahera Barat maka kita tidak usah mengikuti apa yang menjadi persoalan para elit politik lokal. Sultan adalah penentu akhir soal pemekaran di Maluku Utara dan sekarang belum memutuskan. Dalam doa khutbah secara khusus sang Khatib membacakan untuk Sultan Ternate beserta keluarga besarnya yang telah memimpin Ternate dan Maluku Utara.

Apa yang dapat dibaca dari pengkutbah di Masjid tersebut diatas? Tidak ada lain, kecuali hendak memberikan konstruksi pada masyarakat bahwa apapun yang terjadi di Maluku Utara harus menunggu Sultan dan artinya Sultan adalah sosok tunggal yang dipandang paling memiliki otoritas atas persoalan pemekaran di Maluku Utara. Dikala harapan masyarakat pada Sultan demikian tinggi, Sultan bergeming untuk tidak memutuskan enam desa yang sudah 12 tahun konflik pemekaran. Mengapa demikian, inilah yang menjadi pertanyaan maha besar atas Permaisuri Sultan Ternate (Muzzafar Syach), sebagai anggota Dewan Perwakilan Daerah, sementara Ratu Boki Nita sang istri menjadi Anggota Dewan Perwakilan Rakyat (DPR) dari Partai Demokrat. Sungguh menyimpan banyak pertanyaan penting disana. Kita mungkin boleh bertanya, bukankah ini politicking?

Persoalan genting lainnya terkait dengan soal etnisitas dan agama adalah adanya kecenderungan perilaku etnis (suku dan agama) yang menghubungkan soal sukuisme dan chauvinism dalam kaitannya dengan para pemegang saham kekuasaan daerah tentang posisi strategis di daerah. Dalam banyak kasus di daerah pemekaran yang terjadi di Indonesia sejak tahun 2001 hingga 2010 sebenarnya persoalan siapa yang memiliki saham kekuasan menjadi persoalan cukup berpengaruh. Oleh sebab itu, menempatkan posisi para pemilik saham kekuasaan sebagai subjek yang layak menjadi kajian akan menjadikan titik poros persoalan konflik daerah pemekaran semakin kentara karena faktor politik kekuasaan. Saham kekuasaan etnis dan agama tertentu akan berpengaruh pada pola kekerasan yang terjadi disebuah daerah. Maluku Utara termasuk daerah yang kekerasan kolektifnya cukup tinggi, mencapai 2.447 dalam kurun waktu 1999-2003 
seperti dikemukakan Rizal Panggabean. (Panggabean, dalam Koeswinarno dan Dudung Abdurrahman, 2009)

Politik kekuasaan ini seringkali berbasiskan etnis tertentu. Sekalipun kadang berbasiskan agama sebagai determinan. Kasus Poso dan Ambon adalah persoalan agama lebih determinan sekalipun sebagian peneliti dan pengamat lebih suka menempatkan persoalan jarak ekonomi masyarakat pendatang dan pribumi sebagai masalah utamanya. Sementara Maluku Utara dalam kasus enam desa (Bobane Igo, Akesahu, Akelamu, Tetewang, Pasir Putih dan Dum Dum) berbasiskan kesatuan etnis. Reproduksi yang saya katakan pada bagian-bagian awal tulisan ini merupakan metode yang dibangun agar kesamaan dan kesatuan etnis menjadi hal yang dominan dalam menentukan pemilihan wilayah, apakah Halmahera Utara ataukah Halmahera Barat. Kekentalan akan hal ini menjadi basis dalam wacana politik lokal Maluku Utara dari tingkat Provinsi sampai Kecamatan bahkan desa-desa.

Persoalan etnisitas akan menjadi hal yang sangat penting di Maluku Utara, karena sentimen ini merupakan hal yang dominan. Hal ini bisa dirujuk karena akan terkait dengan pihak-pihak yang mengelola kondisi sumber-sumber kekayaan daerah. Seperti kisah di Sulawesi Barat dan Poso sebagai daerah Pemekaran dan areal transmigrasi maka soal etnisitas sangat penting posisinya. Enititas etnis tertentu akan berhasil dalam proses-proses politik jika berhubungan dengan identitas etnis tertentu. Keterkaitan antar etnis akan memudahkan seseorang berada dalam tingkat birokrasi yang mapan dan berlangsung lama sebelum akhirnya terjadi kudeta oleh etnisitas lain yang kemudian hadir dan menjadi etnis yang berpengaruh dalam sebuah pemekaran. Kekerabatan etnisitas dan agama menjadi pola yang kuat dalam masyarakat Sulawesi Barat dan Poso sebagaimana dilaporkan oleh Lorraine V Aragon yang menunjuk pada persaingan anta relit lokal berbasiskan etnis dan agama terutama sejak Orde Baru hampir tumbang tahun 1990-1996. (Lorraine, dalam Henk Schulte Nordhot dan Gerry van Klinken, 2007)

Maluku Utara adalah contoh yang nyaris sama dengan Sulawesi Barat dan Poso. Etnis Makian adalah etnis yang jumlahnya tidak seberapa besar tetapi dalam beberapa tahun sepanjang sejarah Maluku Utara menjadi penguasa. Etnis Makian merupakan etnis yang kuat dalam hal kerja (pekerja keras, semangat maju yang keras, berpendidikan lebih baik ketimbang etnis lain dank arena itu secara ekonomi dan politik lebih beruntung ketimbang etnis lainnya). Namun yang menjadi soal adalah etnis Makian akhirnya dianggap menjadi salah satu etnis yang menjadi sumber konflik dan kerusuhan Maluku Utara ketika berpindah ke Teluk Kao tahun 1999. Kerusuhan yang menimpa etnis Makian ketika pindah dari wilayah lereng Gunung Sei yang diprediksi akan terjadi letusan merupakan hal yang memberikan pertanda lain. (Abu Bakar Muhammad, 2009).
Pendeknya persoalan dominasi etnisitas karena politik, birokrasi, ekonomi, sekalipun jumlahnya etnis Makian tidak siginifikan alias sedikit (18.722 jiwa) tahun 1975 dan tahun 1998 menjadi 20.620 jiwa) akan menjadi persoalan serius terutama dikalangan etnis yang mayoritas, Jailolo, Bacan dan Tobelo-Tubaru. Dari sana mengapa etnis Makian sampai sekarang dianggap sebagai musuh bebuyutan etnis mayoritas di Maluku Utara, Bacan, Jailolo, Tobelo dan Tobaru. Pertanyaan bisa kita ajukan mengapa etnis yang sedikit tersebut bisa terus bertahan dalam birokrasi pemerintahan, dalam penguasaan ekonomi, dan politik lokal sesungguhnya tidak bisa diabaikan begitu saja, sebab selama ini dalam politik etnis kita akan bertemu dengan apa yang kita kenal dengan tradisi. Utamanya kesamaan tradisi seringkali membuat penduduk merasa nyaman dan aman ketimbang berada dalam tradisi yang beragam.

Tradisi sesama etnis dalam perilaku politik, ekonomi dan sosial dengan mudah dapat dipahami sehingga memungkinkan untuk kerjasama politik maupun kerjasama sosial. Apalagi etnis Makian ini secara religi juga relative sama yakni sebagai penganut Islam sehingga akan mudah menerima tradisi dari Islam ketimbang Kristen di wilayah Teluk Kao ataupun Akesahu Gamsungi dan Akesahu apalagi Tobelo yang mayoritas bertradisi Kristiani. Inilah persoalan kesamaan tradisi yang membuat etnis Makian menjadi korban yang sesungguhnya dalam konflik Maluku Utara tahun 1999 yang lalu bahkan sampai sekarang.

Etnisitas dan agama juga bukan hal yang imun dari menggejalanya Korupsi, Kolusi dan Nepotisme $(\mathrm{KKN})$, dari sejak sebelum reformasi sampai orde reformasi bahkan sampai Orde sekarang tahun 20092014. KKN dalam bentuk kesatuan etnis dan agama ditambah dengan kesatuan politik membuat semakin kuatnya gejala KKN yang terjadi dari tingkat pusat hingga daerah pemekaran. Maluku Utara adalah contoh yang tidak berbeda jauh dengan daerah-daerah pemekaran lainnya yang melanjutkan tradisi KKN dalam birokrasi pemerintahan dan feodalisme kekuasaan keagamaan. Pemilihan Walikota Ternate yang melibatkan putra Gubernur (sekalipun akhirnya kalah) dengan kandidat lain adalah hal yang tidak bisa dipungkiri. Apalagi terdengar bahwa dua putra Gubernur akan diajukan dalam Pemilihan Bupati di Kabupaten Maluku Tengah dan Kepulauan Morotai. Inilah sebuah bentuk neo-feodalisme yang telah berlangsung cukup lama dalam tradisi politik Indonesia.

Hal yang juga menjadi persoalan krusial lainnya dalam konflik pemekaran di Maluku Utara adalah terkait konstruksi politik tentang etnis dan keagamaan dalam daerah pemekaran. Disana terjadi apa yang kita kenal dengan sebutan politik diskriminatif atas kelompok etnis dan agama lain. Disini sekaligus bagaimana menafsirkan tentang pendatang atau orang baru dalam daerah pemekaran. Pendatang adalah faktor yang sangat penting 
dimasukan dalam konteks politik pemekaran di Maluku Utara, sekalipun masyarakat sebenarnya tidak seberapa memahami apa itu pendatang dan apa itu penduduk asli. Tetapi reproduski yang kemudian mengkonstruksi masyarakat dalam dua belahan besar: masyarakat asli dan masyarakat pendatang menjadi hal yang tidak terelakan dalam politik pemekaran yang mendasarkan pada etnisitas dan religi-agama. Semuanya jika hendak disambungkan tidak ada lain kecuali adanya keinginan memperpanjang dominasi etnis dan agama dalam sebuah wilayah sehingga etnis dan agama yang berbeda dan bahkan minoritas tidak akan pernah mendapatkan kesempatan dalam birokrasi pemerintahan sampai tradisi politik KKN berubah menjadi tradisi politik professional dan bersih.

\section{Transaksi Politik Lokal Berdasarkan Identitas Etnis}

Nyaris tidak pernah terbantahkan jika dalam sebuah proses politik terjadi transaksi sekaligus persaingan antara elit lokal versus elit pusat. Hal yang paling menyedihkan dan menarik untuk tetap diperhatikan adalah kontestasi dan transaksi berdasarkan etnis. Penjelasan Clifford Geertz dan Malinowsky diatas dapat memberikan penjelas pada kita untuk melihat betapa kepentingan etnis dan agama tidak pernah ditinggalkan dalam persoalan politik lokal maupun nasional. Dalam bahasa lain, perpolitikan kita belum bisa beranjak pada politik yang lebih mentransendensikan etnisitas dan agama sehingga berpolitik lebih mengutamakan pada pensejahteraan publik dan pelayanan masyarakat. Politik kita adalah politik chauvinism yang lebih mendasarkan pada etnis dan agama bukan pada multikulturalisme dan heterogenisasi agama. Multikulturalisme politik dan persaingan politik berbasiskan kapasitas dan profesionalisme belum menjadi tradisi dalam proses politik lokal. Pencitraan memang seringkali dijadikan sebagai metode menggiring massa pemilih untuk menentukan pilihannya, namun sejatinya bukan pada soal profesioalisme dan kapasitas kandidat pemimpin di tingkat daerah (gubernur, walikota ataupun bupati).

Elit ditingkat pusat akan berupaya menyambungkan konteks lokal dengan etnisitas dan agama ketimbang dengan dengan kondisi sosial ekonomi riil yang menjadi kebutuhan masyarakatnya. Hal ini sekaligus memberikan penjelas pada kita bahwa kualitas politisi kita baik tingkat lokal maupun pusat sebenarnya masih pada level mempertahankan identitas secara sempit ketimbang mengembangkan tradisi politik yang terbuka (inkulvisime politik) yang berbasiskan pada kerangka nation state dan keindonesiaan yang majemuk dalam hal etnis dan agama. Identitas agama dan etnis menjadi pokok dalam perhelatan politik lokal, sekalipun tidak jarang menghasilkan kerusuhan massal karena sentimen etnis dan agama bermain secara tak beraturan. Kita dapat saksikan misalnya dalam hal poster-poster kandidat kepala daerah atau kandidat bakal anggota legislative, hampir selalu menyertakan sebutan ASLI dan DARI. Dua kata ini merupakan ungkapan untuk secara tegas memberikan deskripsi singkat bahwa dirinya adalah sosok yang dianggap merasa dan dirasa akan mewakili aspirasi masyarakat ketika nanti terpilih. Bahwa nanti setelah terpilih yang terjadi adalah transaksi politik antar elit lokal dengan pusat atau tidak menjadi representasi merupakan persoalan lain.

Maluku Utara adalah eksemplar yang menarik untuk dibaca dalam konteks gagasan merayakan kemajemukan politik berdasarkan agama dan etnis. Hal ini karena di Maluku Utara persoalan etnis dan agama sebagaimana saya kemukakan diatas menjadi penyanggap politik identitas yang bermakna sempit (bukan bermakna keindonesiaan). Etnisitas dan agama adalah komoditas politik yang masih mampu menghadirkan banyak kebentungan politik pada kandidat yang hendak bertarung. Identitas etnis dan agama merupakan salah pijakan seseorang hendak maju dalam Pemilukada dan Pemilu legislatif. Ungkapan lain yang juga popular adalah penggunaan bahasa lokal yang hanya dimengerti oleh mereka dan masyarakatnya, bukan orang lain. Ungkapan dengan bahasa lokal merupakan penggambaran paling jelas untuk menarik simpatik dan sentimen etnisitas dalam proses politik di Maluku Utara.

Bahkan penggunaan gelar kedaerahan dan keagamaan merupakan hal yang ramai dipakai dalam proses politik di Maluku Utara, misalnya menempelkan gelar etnis tertentu, Jiko Ono, Tuan Haji Atau Tuan Guru dan seterusnya. Semuanya dapat dibaca sebagai cara mengaitkan identitas etnis dan agama dalam proses politik berlangsung. Memang terdapat kandidat yang mengusung slogan bergaya metropolitan namun tak dapat meghipnotis masyarakat, bahkan dikesankan lelucon belaka. Kandidat menggandeng Presiden Amerika Obama bersalaman dan bersanding dengan dirinya. Begini ungkapannya: "Selamat Om Bama, Anda menjadi Presiden Amerika. Doakan saya menyusul kesuksesan Om Bama. Obama menjawab: Saya doakan semoga Anda Sukses, sambil berjabat tangan!"

Soal lainnya yang perlu menjadi perhatian kita adalah selain adanya transaksi berdasarkan kesamaan etnis dan agama, di Maluku Utara sebenarnya berlangsung pertarungan antara Elit lokal versus elit lokal berdasarkan etnis. Kondisi ini sangat kuat dan kentara dalam konflik pemekaran enam desa yang tak kunjung selesai sampai sekarang. Antar elit lokal berdasarkan etnis tertentu mendorong terjadinya hegemoni dan dominasi dalam pemerintahan dan birokrasi ketimbang berbagi etnisitas sesama warga Maluku Utara. Hal ini tentu saja membuat semakin runyamnya politik di Maluku Utara karena antar etnis tidak bersedia akur apalagi duduk bersama untuk membahas masa depan daerah pemekaran. Perhatikan komentar salah seorang birokrat dibawah ini yang bukan asli dari Maluku Utara sekalipun sudah puluhan tahun di Maluku Utara. 
"Disini namanya etnistas sangat kuat. Jika ada salah seorang pejabat dari etnis tertentu, dia akan membawa serta etnis kelompoknya dalam birokrasi. Hal ini yang menyebabkan adanya KKN dalam politik di Maluku Utara dan akan terus terjadi ketika antara etnis di Maluku Utara tidak segera memutus mata rantai etnisitas tersebut. Hal yang dikhawatirka adalah adanya politisasi etnis untuk kepentingan politik kelompok etnis sebagaimana sekarang terjadi dalam Pemekaran Kabupaten Halmahera Utara dan Halmahera Barat". (AB, 19 Agustus 2010)

Oleh karena politik Maluku Utara berdasarkan pada sendi etnis dan agama maka hampir dipastikan bahwa dalam birokrasi pun akan terjadi pertarungan antar kelompok etnis yang sedang berkuasa dan bersiap akan berkuasa. Dalam Elit lokal dengan birokrasi pemerintahan identitas etnis akan menjadi hal yan krusial dan perlu diperhatikan sehingga membaca konflik pemekaran Maluku Utara bisa dikatakan tidak bisa tanpa memperhatikan dimensi etnisitas dan agama dalam politik. Bahkan yang paling membahayakan adalah sebagaimana dalam politik pemekaran di daerah lain soal asal usul etnis terjadi pula di Maluku Utara. Elit lokal mempergunakan etnisitas dan agama sebagai perekat politiknya sehingga dimensi etnis dan agama tidak dapat lepas dari apa yang disebut sebagai sandera politik etnis dan agama, sebab itukah buffer zone politik lokal yang sampai sekarang dipelihara.

Elit lokal dengan tentara setempat dan tentara dari lain dari pun tak jarang berkolaborasi dalam KKN politik di Maluku Utara. Politik berdasarkan latar belakang etnis dan asal usul daerah menjadi faktor yang juga berpengaruh dalam politik pemekaran di Maluku Utara. Sungguh pun dalam banyak hal tidak menguntungkan untuk pengembangan daerah pemekaran, namun tradisi menghubungkan daerah asal dan menghubungkan dengan tentara menjadi faktor yang cukup berpengaruh dalam tradisi politik di Maluku Utara. Inilah yang selama ini juga telah menjadi perhatian oleh para peneliti dan penulis tentang politik Maluku Utara. Konflik Maluku Utara tidak pernah imun dari kehadiran tentara yang berlatar belakang etnis dan agama sama dengan elit politik yang berkuasa. Tulisan Abu Bakar Muhammad memberikan penjelasan soal seperti ini. (Abu Bakar Muhammad, 2009)

\section{Agenda-Agenda Politik Identitas Etnis dan Agama}

Pemilihan gubernur, bupati, walikota dan pemilihan legislatif merupakan agenda politik yang terjadi di Maluku Utara. Kontestasi antarcalon gubernur, bupati, walikota dan anggota legislative tidak pernah sepi dari persaingan antar kontestan yeng berlatar belakang etnis dan agama tertentu. Benar bahwa persoalan agama tidak demikian menguat, tetapi kita dapat saksikan betapa pemberlakuan formalism agama menjadi bagian dalam tradisi politik Maluku Utara. Setiap Jumatan misalnya, jalan raya yang melewati masjid mesti ditutup tidak boleh terdapat kendaraan melewatinya. Jika ada yang melewatinya akan ditangkap dan dihukum oleh masyarakat.

Daerah Halhamera Utara dan Halmahera Barat salah pusat yang dalam politik lokal menjadi penting diperhitungkan. Enam desa merupakan wilayah potensial dengan sumber daya alam dan etnis yang beragam dan agama beragam. Akelamo berpenduduk mayoritas (100\%) muslim. Akesahu mayoritas Kristen dengan hanya 18 kepala keluarga (KK) beragama Islam. Bobani Ego mayoritas muslim, Dum-Dum 100 $\%$ Kristen, Tetewang mayoritas muslim, dan Pasir putih mayoritas Kristen. Dari enam desa yang ada, penduduk terpadat adalah Bobani Ego dan Akelamo, dengan jumlah penduduk $233 \mathrm{KK}$, Bobani Ego 487 KK, sedangkan empat desa lainnya adalah: Akesahu 668 jiwa; Tetewang 668 jiwa; Pasir Putih 544 jiwa, Dum Dum 110 KK. (Team Peneliti PSKP UGM, 2010)

Dengan kondisi penduduk semacam itu, elit lokal seringkali bermain dalam proses politik lokal dengan memanfaatkan sentimen etnis dan agama sebagai pemantiknya. Ketika riset ini berlangsung misalnya, adalah waktu yang sudah berdekatan dengan Pemilihan Walikota Ternate, dimana salah seorang calon berasal dari etnis Bacan dan Jailolo sehingga situasi etnis cukup menonjol disana. Bahkan ketika salah satu pasangan kalah masih menggugat ke MK sekalipun akhirnya kalah. Dan ketika pemilihan bupati hendak berlangsung gambar dari masingmasing calon sangat gencar beredar di Akelamo, Akesahu, Bobani Ego, Tetewang, Pasir Putih dan Dum Dum yang berlatar belakang etnis tertentu sebagai latar belakangnya. Situasi etnisitas dan agama sangat terasa di desa-desa tersebut.

Hal yang paling jelas terlihat lainnya adalah adanya Forum Komunikasi Kepala Desa di enam desa yang diketuai seorang mantan kepala desa dan mantan angota dewan. Forum Kepala Desa ini sangat keras penolakannya terhadap penggabungan atas enam desa menjadi wilayah Halmahera Utara dengan argument sejak nenek moyang merupakan etnis Jailolo Timur, bukan Tobelo sebaai ibu kota Halmahera Utara. Situasi kental etnis dan agama behubungan satu dengan lainnya. Dimana kepala desa desa Kristen adalah seorang Kristen, sedangkan kepala desa muslim adalah seorang muslim. Benar bahwa disana mayoritas Kristen atau Muslim tetapi yang menjadi perhatian adalah ikatan emosional etnisitas dan agama menjadi dinomor satukan ketimbang persoalan pelayanan pada masyarakat yang telah dua belas tahun dilanda konflik pemekaran (1999-2010). Identitas keagamaan dan etnisitas benar-benar menjadi ikatan emosional warga masyarakat Maluku Utara dalam menghadapi Pemilukada (bupati maupun walikota dan Pemilu Legislatif). Hal ini yang pantas diperhatikan seksama.

Perilaku elit dalam politik pemekaran berdasarkan kultur dan etnis sangat nyata terjadi di Maluku Utara. Itu yang kiranya dapat menjelaskan 
mengapa konflik pemekaran di Maluku Utara tak kunjung usai dalam proses penyelesaian. Hal ini karena masing-masing etnis membawa agendanya sendiri-sendiri sebagai bagian dari politik patronase atau kongkalikong antara elit tingkat pusat dengan elit tingkat daerah (gubernur dan bupati sekaligus walikota). Politik patronase dan kongkalikong sekalipun banyak dikecam orang dan ahli politik yang berpaham demokratis dan anti feodali namun dalam prakteknya terus berjalan dan tampaknya menguntungkan dalam tradisi politik lokal seperti di Maluku Utara. Patronase merupakan bagian tak terpisahkan dalam kultur politik lokal.

Oleh sebab itu, agak sulit diselesaikan ketika dimensi politik etnis dan agama masih dijadikan kendaraan permainan politik lokal. Persoalan politik pemekaran hanya akan berkembang pada tingkat elit lokal dan nasional yang memiliki agenda-agenda politik mempertahankan dominasi politik, ekonomi, birokrasi dan budaya. Pemekaran benar-benar akan memperbanyak jumlah birokrasi, pejabat dan politisi tetapi minim pelayanan publik sebagaimana kita jumpai di Maluku Utara, khususnya pada enam desa. Terjadi dualism pemimpin lokal (desa) tetapi miskin fasilitas apalagi kemakmuran daerah. Yang menikmati pemekaran adalah elit lokal di masing-masing kabupaten, dan desa, sementara warga masyarakat hanya menjadi bagian dari komoditas politik elit lokal yang suaranya dibutuhkan ketika terjadi perhelatan politik lima tahunan.

\section{SIMPULAN}

Setelah kita baca apa yang terjadi pada pemekaran di Halmahera Barat dan Halmahera Utara pada enam desa, sesungguhnya kita mendapatkan konstruksi politik pemekaran pada tingkat elit politik, konstruksi pada masyarakat mayoritas dan masyarakat minoritas. Pada tingkat elit, pemekaran adalah jalan keluar untuk mengatasi sentralisasi kekuasaan pusat pada desentralisasi kekuasaan. Prinsip desentralisasi yang didefinisikan dalam tiga kategori: (1) sebagai delegasi tugas-tugas tertentu sementara pusat masih menguasai beberapa sentra-sentra kekuasaan secara keseluruhan yang dapat diperbandingkan dengan UU tahun 1974; (2) sebagai dekonsentrasi yang mengacu pada pergeseran decision making dalam Negara sentralistik, yang tercermin dalam UU tahun 1975; dan (3) sebagai devolusi, yang menyangkut transfer kekuasaan secara aktual ketingkat pemerintahan yang lebih rendah dan diimplementasikan pada tahun 2011.

Dalam tiga tafsir pemekaran itulah proses politik di daerah dan pusat tidak pula segera terselesaikan dengan baik. Bahkan dalam beberapa kasus pemekaran, sebagaimana dievaluasi oleh lembaga-lembaga survei semacam Lembaga Survei Indonesia, $88 \%$ daerah pemekaran sebenarnya telah gagal dalam menjalankan filosofi dari pemekaran itu sendiri, karena politik lokal daerah pemekaran berjalan pada feodalisme kepemimpinan yang pernah berjalan pada zaman orde sebelum pemekaran, yakni zaman orde sentralisasi. Persoalan politik pemekaran karena masih banyaknya kepentingan sentimen etnis dan kelompok dominan ketimbang politik yang mementingkan kesejahteraan dan kemakmuran serta keamanan masyarakat umum.

Peta konstruksi elit tentang pemekaran jauh berbeda dengan konstruksi kaum minoritas dan masyarakat. Kaum minoritas secara etnis dan agama memandang bahwa pemekaran merupakan agenda politik kaum elit yang memiliki kepentingan memperpanjang dominasi kekuasaan dan menguasai masyarakat secara legal dan disyahkan karena melalui proses politik Pemilu lokal yakni Pemilukada (pemilihan gubernur, walikota, dan bupati). Dari sana elit politik lokal mendapatkan kesempatan untuk mengklaim mendapatkan mandat dari rakyat banyak sekalipun dalam perilaku politiknya tidak membela kepentingan rakyat.

Memperhatikan peristiwa politik pemekaran di Maluku Utara dua hal menjadi sangat dominan yakni identifikasi etnis dan agama menjadi bagian tak terpisahkan dalam proses politik. Identitas etnis dan agama menjadi bungkus yang mujarab untuk melakukan penolakan atau penerimaan sebuah kehendak pemekaran. Pemekaran dengan begitu tidak lain kecuali sebagai sebuah proses dari apa yang oleh Clifford Geertz sebut sebagai involusi. Inilah Involusi politik karena berbasiskan etnisitas dan religi.

\section{DAFTAR PUSTAKA}

Abu Bakar, Muhammad. 2009. Merajut Damai di Maluku Utara. UMMU Press.

Antlov, Hans. 2002. The State in the Country. Yogyakarta: Lappera.

D. Harmantyo. 2007. Pemekaran Daerah dan Konlik Keruangan, Kebijakan Otonomi Daerah dan Implementasinya di Indonesia. Jakarta: Makara. Sains. Vol. 11, No.1, April 2007. Dept. Geografi UI.

Decentralization Support Facility. 2007. Proses dan Implikasi Sosial Politik Pemekaran, Studi Kasus di Sambas dan Buton, Laporan. Unpublish. Jakarta.

Direktorat Jenderal Pemerintahan Umum, Depdagri. 2008. Rekapitulasi Permasalahan Perbatasan antar Provinsi, Laporan. Unpublish. Jakarta.

Donald K Emmerson. 2001. Beyond Suharto, Politics, Economy and Power. Australia: University

Faisal Bakti, Andi, (ed.). 2000. Good Governance and Conflict Resolution in Indoensia. Jakarta: Logos.

Geertz, Clifford. 1958. Religion of Java. USA. 1967. Islam Observed. Chicago University, USA.

Hancoock. (2007). The Gods of Poverty. Yogyakarta: Pustaka Cinderalas.

Henk Schulte Nordholt and Gerry van Klinken. 2007. Local Politics in Indonesia. Jakarta: Yayasan Obor Indonesia. KITLV. 
Henk Schulte, Nordhot dan Gerry van Klinken. Politik Lokal di Indonesia.

Irfan Abu Bakar (ed.). 2005. Transisi Politik dan Konflik Kekersan. Jakarta: UIN.

Jones, Stephen, B. 2000. Boundary Making, A Handbook for Statesmen, Treaty Editors and Boundary Commissioners. New York: William S. Hein \& Co.,Inc. Buffalo.

Kausar dan Eko Subowo. 2008. Kebijakan Penataan Batas Antar Daerah. Modul pelatihan Penegasan Batas Daerah. Yogyakarta: Jurusan Teknik Geodesi FT UGM. Unpublish.

Koeswinarno dan Dudung Abdurrahman. 2006. Fenomena Konflik Sosial di Indonesia. Yogyakarta: UIN Sunan Kalijaga.

KPU, North Maluku Province 2009.

Kuntowijoyo. 2001. Muslim Tanpa Masjid. Bandung: Mizan.

Leo Agustino. 2010. A political Dynasty After the Autonomy of the new order: The Experience of Banten. Prism. Vol 29, No. 3, July 2010,

Mochtar Masoed. 1987. The Structure of The Political Economy of The New Order 1966-1985. Jakarta: LP3ES.

Muhamin, A. Yahya. 1991. Business and Politics of the New Order Era. Jakarta: LP3ES. of Melbourne.

Rasyid, Ryaas, M. 2002. Otonomi Daerah: Latar Belakang dan Masa Depannya. Workshop Desentralisasi, Demokratisasi dan Akuntabilitas Pemerintah Daerah. Cetakan ketiga. Jakarta: LIPI Press.

Ratnawati, Tri. 2009. For Sea Areas: Lokal Politics and The Issues Selected. LIPI.

Safuan, Razi. 2001. Communal Violence and conflict resolution: Anatomy in Indonesia. Jakarta: LIPI.

Subowo, E. 2009. Makalah disampaikan pada FGD Permasalahan Konflik Batas Wilyah. 24 Desember 2009 di Jurusan Teknik Geodesi Fakultas Teknik UGM.

Sutisna, Sobar, Sora Lokita dan Sumaryo. 2008. Boundary Making Theory dan Pengelolaan Perbatasan di Indonesia. Workshop Pengelolaan Wilayah Perbatasan. Yogyakarta: Jurusan Ilmu HI/UPN Veteran. November.

Syafuan Rozi (dkk.). 2006. Kekerasan Komunal, Anatomi dan Resolusi Konflik di Indonesia. 2006.

Team Pusat Studi Keamanan dan Perdamaian. 2010. UGM, Laporan Assesment di Enam Desa Kabupaten Halmahera Barat.

TK, Ommen. 2007. Citizenship, Nationality and Ethnicity, Creation of discourse. Yogyakarta. 2009. Kewarganegaraan, Kebangsaan dan Etnisitas.

Vivian Louis Forbes. 2001. Conflict and Cooperation in Managing Maritime Space in Semi-enclosed Seas. Singapore: Singapore University Press, Yusof Ishak House.

Welfizar. 2004. Analisis Alternatif Kebijakan Penyelesaian Konflik Perubahan Batas Wilayah Kota Bukittinggi dan Kabupaten Agama. Yogyakarta: Program Studi Magister Adminstrasi Publik, Konsentrasi Kebijakan Publik, Pasca Sarjana UGM.
Winters, Jeffry. 2007. Democracy and Oligarchy. Gramedia Pustaka Utama.

Zartman, I William. 1997. Governance as Conflict Management: Politics and Violence in West Africa. USA: Washington DC. 